\title{
Clipping herbaceous vegetation improves early performance of planted seedlings of the Mediterranean shrub Quercus coccifera
}

\author{
J. M. Rey Benayas, A. Fernández and A. Aubenau
}

Rey Benayas, J. M., Fernández, A. and Aubenau, A. 2007. Clipping herbaceous vegetation improves early performance of planted seedlings of the Mediterranean shrub Quercus coccifera. - Web Ecology 7: 120-131.

\begin{abstract}
We tested how the conditions resulting from alternative management strategies addressed to mitigate abiotic and biotic limitations to plant establishment affect the performance of planted Quercus coccifera seedlings. This species is a xerophytic and heliophillous Mediterranean shrub, of interest for the restoration of abandoned farmland. We hypothesised that release from herb competition by clipping would allow $Q$. coccifera seedlings to cope more efficiently with water shortage by adjusting their mass allocation pattern. We established three environments of herb competition: absence of competition (AC), reduced competition by clipping (RC), and total competition (TC); and applied two irrigation treatments: low and high irrigation. We measured soil moisture at different depths, above- and below-ground herb biomass, and evaluated seedling responses, such as mortality, growth, biomass allocation, and morphological and physiological features. The TC treatment reduced water availability more than the RC treatment, in agreement with the highest water stress of seedlings under TC conditions. Irrigation increased above- and below-ground herb biomass, whereas clipping reduced herb production. Release of herb competition by clipping increased seedling survivorship by one order of magnitude and resulted in a growth rate comparable to the absence of competition. This growth was mostly related to carbon gain allocated to roots. The competition intensity imposed by treatments was related to a parallel reduction in total plant leaf area, biomass allocated to leaves and shoot:root ratio, and an increase in biomass allocated to roots and leaf mass area. The negative effects of herbs on $Q$. coccifera seedlings seem the result of competition for both water and light, in contrast with previous research with more mesic Quercus species, for which competition is primarily for water. Clipping of herbs is a feasible technique that greatly improved seedling performance, and thus a valuable alternative to herbicide application, common in native plantations aimed at restoring Mediterranean farmland.
\end{abstract}

J. M. Rey Benayas (josem.rey@uah.es), A. Fernández and A. Aubenau, Departamento de Ecología, Universidad de Alcalá, Alcalá de Henares, ES-28871, Spain.

In tracts of land dominated by herbaceous vegetation, the establishment of shrub and tree species is influenced by the ability of woody seedlings, either planted or naturally established, to survive and grow in direct competition with herbs (Morris et al. 1993, Brown et al. 1998, Holl 1998, Davis et al. 1999, Hooper et al. 2002). The re-vegetation of these habitats, such as abandoned cropland with native, well-adapted evergreen shrubs would render a number of environmental benefits (Vieira et al. 1994, Whisenant et al. 1995, Padgett et al. 2000). However, techniques for successful establishment of these species have not been fully developed (Vilagrosa et al. 2003a). This issue may 
have important economic consequences because large amounts of public and private funds are invested in cropland reforestation (Rey Benayas et al. 2007, 2008).

In abandoned Mediterranean croplands, the survival and growth of woody plants are limited by high radiation and low water availability during summer, and by herbs which are strong competitors for resources, particularly water year round (Canham et al. 1996, Rousset and Lepart 2000, Rey Benayas et al. 2005). Herbs can deplete both below- (water and nutrients) and above-ground (light) resources faster than woody seedlings during their peak of growth because they allocate a larger proportion of biomass to productive tissues (Hunt and Cornelissen 1997). Acclimation to water shortage takes place mainly through a decrease in the shoot:root ratio (Joffre et al. 2001) and the exposed leaf area (Rambal and Leterme 1987, Sala et al. 1994, Castro-Díez et al. 1997, Valladares and Pugnaire 1999). In contrast, acclimation to low light availability occurs via reverse trends (Balaguer et al. 2001). Thus, it seems difficult to respond to both types of shortage efficiently (Valladares 2001).

Low water availability can be ameliorated by irrigation, a practice that also benefits herbs (Rey Benayas et al. 2002). Herb competition is usually mitigated by herbicides (Peñuelas et al. 1996, Sternberg et al. 2001), but this practice also eliminates the potential benefits of herbs for woody seedlings such as reduction of photo-inhibition damage and to soils, e.g. carbon enrichment and erosion control, and may contaminate soil and water.

We hypothesized that clipping the aboveground portion of weedy herbs could enhance the performance of transplanted woody seedlings by increasing soil water availability. Additionally, by reducing the shade imposed by tall herbs, shrub seedlings will cope more efficiently with water shortage by adjusting their mass allocation pattern appropriately. We also hypothesized that herb competition will be more critical for woody seedling establishment than irrigation because the positive effects of irrigation on shrubs may be cancelled out, at least partially, by an increase in competition with herbs. To test these hypotheses, woody seedlings were planted under three levels of weed competition: 1) absence of competition where no herbs were planted designed to mimic herbicide application, 2) reduced competition by repeated clipping of the aboveground biomass, and 3) total competition where no management intervention was used. Each of these treatments were tested under two water regimes (low and high). If seedlings under reduced competition by clipping perform satisfactorily when compared to those under total competition, mowing of herbaceous vegetation may be an environmentally-friendly alternative to herbicides. If irrigation favours herb competition, then it may not pay to apply this technique unless seedlings are growing in an environment with released competition from herbs.

Our aim was to investigate alternative management to mitigate abiotic and biotic limitations for establishment in dry environments of planted Quercus coccifera L. seedlings. We assessed the response of seedlings to the interactive effects of different levels of herb competition and water availability. We expect that our experimental results will provide evidence of mechanistic responses of seedlings to limiting factors, and a baseline for management in restoration projects.

Quercus coccifera is a heliophyllous evergreen shrub 2-3 $\mathrm{m}$ tall, growing in sites with low precipitation, high sun radiation, and soils with little water holding capacity (Paraskevopoulos et al. 1994, Rambal et al. 1996, Laaidi 1997). It is an important species for re-vegetation because it is a major structural component of the native plant communities thriving in large areas of the Mediterranean ba$\sin$.

\section{Methods}

\section{Study site}

The study was conducted at the Juan Carlos I Botanical Garden, in Alcalá de Henares University, central Spain $\left(40^{\circ} 35^{\prime} \mathrm{N}, 3^{\circ} 25^{\prime} \mathrm{W}\right)$. In the area, mean annual temperature is $13.5^{\circ} \mathrm{C}$ and annual precipitation averages $450 \mathrm{~mm}$, with a pronounced summer drought. Total precipitation during the experiment (February to October - end of the growing season, 2000) was $266.2 \mathrm{~mm}$, and temperature averaged $17.4^{\circ} \mathrm{C}$.

\section{Experimental design}

One-year old Q. coccifera seedlings were grown in $20 \mathrm{~cm}$ deep containers under homogenous nursery conditions of frequent watering and high fertilization. They averaged $22.6 \pm 6.04 \mathrm{~cm}$ in height and $4.17 \pm 0.85 \mathrm{~mm}$ in diameter. In early February 2000, sixty seedlings were individually planted in polyethylene containers $(40 \mathrm{~cm}$ diameter and $80 \mathrm{~cm}$ deep) filled with the local haploxeralf soil according to the Soil Taxonomy System (USDA 1995). Texture characteristics are the following: coarse sand $=5.4 \%$, fine sand $=39.3 \%$, silt $=37.6 \%$ and clay $=17.8 \%$ (soil texture class is clayey loam). Soil completely filled the containers. The upper soil layer $(4-5 \mathrm{~cm})$ was rejected to avoid the natural herb seed bank. Seedlings were planted with their plugs. All containers were left outdoors and exposed to full sunshine. We added 31 of water per container right after plantation to eliminate soil cavities and because plantations are commonly carried out on wet soil.

The experiment consisted of six treatments that included the combination of three herb competition levels and two irrigation levels, each with 10 planted seedlings of $Q$. coccifera. The herb community was simulated by sowing a seed mixture that consisted of $15 \mathrm{~g}$ of Lolium rigidum seeds 
and $5 \mathrm{~g}$ of Medicago sativa seeds per container, in midFebruary. The seed mixture that we used ensured a strong competition effect and similar competition intensity, density, and species composition in all containers with equal treatment (Kollmann and Reiner 1996).

The herb competition levels were 1) absence of competition (AC), 2) reduced competition by clipping (RC), and 3) total competition (TC). The seed mixture was not added to the AC treatment. Immediately after sowing, we added 11 of water per container to foster seed germination, and another liter of water per container was added one week later. Besides irrigation right after planting and sowing, we added $0.75,4,0.5$, and 31 of water per container at different times during the experiment to avoid excessive soil desiccation. In the RC treatment, herbs were clipped ten times, with an average periodicity of two weeks, from early April. This clipping frequency maintained herbs at less than $8 \mathrm{~cm}$ aboveground, a lower height than the average height of terminal buds in the planted $Q$. coccifera seedlings. Repeated clipping provided minimal aboveground competition, but may also reduce below-ground competition (Briske and Anderson 1992, Taylor et al. 1997). For the TC treatment, herbs were left to grow freely and attained an average height of $60 \mathrm{~cm}$ at the end of the experiment.

We applied the differential irrigation treatments after June, when the summer drought started. There were two irrigation levels: (1) low irrigation and (2) high irrigation. In the low irrigation treatment, $20 \mathrm{l} \mathrm{m}^{-2}$ of water were added to each container every two weeks. In the high irrigation treatment, we added $40 \mathrm{l} \mathrm{m}^{-2}$ every week (four times greater than the low irrigation). Based on previous experience, we did not include a control treatment in which water availability was not directly manipulated because containers create such artificially dry environments that virtually all planted seedlings would have died.

\section{Measurements}

Seedling shoot mortality was assessed before the application of irrigation and at the end of the experiment. We considered a seedling to be dead if all of its above-ground shoots were clearly dry. We are aware, though, that some of these seedlings could re-sprout later, under less stressful conditions.

For semi-destructive and destructive measurements, five randomly selected live seedlings per treatment were sampled before the application of irrigation. Before this sampling, pre-dawn $\left(\varphi_{\mathrm{pd}}\right)$ and mid-day $\left(\varphi_{\text {min }}\right)$ leaf water potentials were measured with a Scholander chamber. After this procedure, harvested seedlings were taken to the laboratory and were separated into their leaf, stem, and root fractions. Total fresh leaf area was measured with a delta-T leaf area meter. Roots were gently washed and the three plant fractions were dried in an oven at $80^{\circ} \mathrm{C}$ for $48 \mathrm{~h}$ before weighing. The roots were incinerated at $550^{\circ} \mathrm{C}$ and the ash weight was subtracted to eliminate the weight of mineral residue. Then, we measured total biomass and the proportion of biomass allocated to leaves, stems, and roots.

We took the average of two chlorophyll-a fluorescence measures per live seedling at the end of June with a Plant Efficiency Analyser (PEA). We inferred a Performance In$\operatorname{dex}\left(\mathrm{PI}_{\mathrm{ABS}}=\left[\mathrm{F}_{\mathrm{M}}-\mathrm{Fo}\right] / \mathrm{F}_{\mathrm{M}}\right)$, which is an overall value that combines parameters related to the photochemical efficiency of photo-system II (Strasser et al. 1996).

For seedling growth, a reference value of initial seedling weight was obtained by weighing ten seedlings prior to the experiment and it averaged $10.63 \mathrm{~g} \pm 1.87$. This reference value was compared with the total biomass of sampled seedlings before irrigation.

Soil moisture was measured four times prior to the irrigation treatments (mid-March, twice in May and at the end of June) at 15, 30, and $45 \mathrm{~cm}$ depth using the TRIME-method, a specially designed TDR technique.

Clipped herbs were dried at $80^{\circ} \mathrm{C}$ and weighed to estimate the accumulated above-ground herb biomass from the ten clippings in the RC treatment. At the end of the experiment, the above-ground herb biomass in the TC treatment was also measured, and samples of the roots of herbs in the RC and TC containers were taken at a depth of 15,30 , and $45 \mathrm{~cm}$ depth using $60.8 \mathrm{~cm}^{2} \times 5 \mathrm{~cm}$ diameter cores. These samples were gently washed to separate roots from substratum, dried in an oven at $80^{\circ} \mathrm{C}$ for $24 \mathrm{~h}$ and then were incinerated before weighing.

\section{Data analysis}

Statistical analyses were based on $\chi^{2}$ to test the effects of treatments on seedling mortality, and on one-, two-, or three-way fixed ANOVA to test treatment effects (competition and irrigation) and soil depth on the rest of the data. Because five seedlings per competition treatment were sacrificed before irrigation and seedling mortality during the irrigation treatment was very high (below), the resulting experimental design was highly unbalanced with very little statistical power. Thus, we factored out the sampling period (pre-irrigation and irrigation) and most Q. coccifera response variables were analysed just for competition effects (namely water potential, biomass allocation and total biomass). At the end of the experiment we measured and analysed seedling total leaf area, leaf mass area ratio (LMA, leaf dry weight per leaf area) and biometric variables. However, these parameters will not be consider further in this study.

For testing differences in soil moisture, we performed a repeated measure ANOVA for similar period intervals before the application of irrigation, and an ANOVA for the data points taken during the irrigation treatment. A repeated measures ANOVA on the four measurements would violate the assumption of sampling equal period in- 
tervals. ANOVA assumptions were tested before its application, and no data transformation was needed. Tukey's tests were used for post-hoc comparisons. We also correlated the amount of accumulated herb above-ground biomass production with soil moisture at different depths and with the average profile moisture for the $\mathrm{RC}$ treatment. Fluorescence was not evaluated in the TC treatment due to accidental loss of data. All statistical analyses were performed with STATISTICA ver. 6.0 (StatSoft 1984-2003).

\section{Results}

\section{Soil moisture}

Competition, soil depth, and time affected soil moisture before the application of irrigation (Table 1). Soil moisture progressively decreased throughout the growth period in the presence of herbs. The difference between treatments with herbs (RC and TC) was usually smaller than between the AC and RC treatments (Fig. 1). The differences between $\mathrm{AC}$ and treatments with herbs increased with soil depth (Fig. 1). For the end-of-June measurements (irrigation treatment), we also found a significant effect of competition, depth (results not shown) and irrigation $\left(\mathrm{F}_{1,116}=\right.$ 143.1, $\mathrm{p}<0.0001)$. Soil moisture was higher under high irrigation $(13.35 \% \pm 4.17)$ than under low irrigation $(9.17 \% \pm 3.61)$.

There was an overall negative relationship between the accumulated herb above-ground biomass and the average moisture across the soil profile in the $\mathrm{RC}$ treatment (Pearson's $r=-0.53, p=0.11, n=10$ ). This relationship was dependent on soil depth, and was only observed at the $15 \mathrm{~cm}$ depth (Pearson's r $=-0.64, \mathrm{p}=0.047, \mathrm{n}=10$ ) and not at the $45 \mathrm{~cm}$ depth (Pearson's $\mathrm{r}=-0.37, \mathrm{p}=0.3, \mathrm{n}=10$ ).

\section{Herb production}

Both clipping $\left(\mathrm{F}_{1,15}=4.6, \mathrm{p}=0.048\right)$ and irrigation $\left(\mathrm{F}_{1,15}=\right.$ 13.6, $\mathrm{p}=0.0022$ ) affected herb above-ground production, which was higher under TC and high irrigation conditions than under RC and low irrigation conditions (Fig. 2a). Clipping marginally reduced herb root biomass $\left(\mathrm{F}_{1,36}=\right.$ $3.85, \mathrm{p}=0.067)$ whereas high irrigation increased it $\left(\mathrm{F}_{1,36}\right.$ $=5.2, \mathrm{p}=0.029$ ) (Fig. 2b). There were no differences in herb root biomass across the soil profile $\left(\mathrm{F}_{2,36}=1.37, \mathrm{p}=\right.$ $0.26)$. Herb production was very variable in the TC and low irrigation treatments.

\section{Seedling mortality}

Before the application of irrigation, competition increased seedling mortality $\left(\chi^{2}=26.1, \mathrm{p}<0.0001, \mathrm{df}=2\right)$. At that time, no seedlings died in the AC treatment, while one $(5 \%)$ died in the RC treatment and $12(60 \%)$ died in the TC treatment (Fig. 3). However, we did not find mortality to be significantly affected by competition $\left(\chi^{2}=4.0, \mathrm{p}=\right.$ $0.137, \mathrm{df}=2)$ or by irrigation $\left(\chi^{2}=0.01, \mathrm{p}=0.91, \mathrm{df}=1\right)$ after irrigation took place. At the end of the experiment, all non-sacrificed seedlings in the AC treatment were alive, while three out of 15 seedlings died in the RC treatment (one died in each irrigation treatment) and 13 out of 15 seedlings died in the TC treatment (one died under low irrigation conditions) (Fig. 3).

\section{Water potential and chlorophyll fluorescence}

$\varphi_{\mathrm{pd}}$ and $\varphi_{\min }$ differed among competition treatments. Seedlings in the TC treatment had more negative $\varphi_{\mathrm{pd}}$ and $\varphi_{\min }$ than those in the $\mathrm{AC}$ and $\mathrm{RC}$ treatments (Fig. 4).

The fluorescence Performance Index did not differ between the AC and RC treatments $\left(\mathrm{F}_{1,22}=0.03, \mathrm{p}=0.86\right)$ nor between irrigation treatments $\left(\mathrm{F}_{1,22}=1.72, \mathrm{p}=0.2\right)$.

\section{Growth and biomass partitioning}

Total seedling biomass was different among competition treatments (Table 2; $\mathrm{F}_{2,12}=4.55, \mathrm{p}=0.033$ ), ranking $\mathrm{TC}<$ $\mathrm{RC}=\mathrm{AC}$. Dry biomass of TC seedlings virtually did not increase from the beginning to the end of the experiment (see Methods for initial reference value).

Table 1. Results of a repeated-measure ANOVA used to test the effects of weed competition, soil depth, and time on soil moisture before the application of the irrigation treatment.

\begin{tabular}{lllll}
\hline Effect & df effect & df error & F & p-level \\
\hline Weed competition & 2 & 60 & 243.1 & 0.0001 \\
Soil depth & 2 & 60 & 5.3 & 0.0068 \\
Time & 2 & 180 & 32.9 & 0.0001 \\
Weed competition $\times$ soil depth & 4 & 60 & 4.4 & 0.0029 \\
Weed competition $\times$ time & 4 & 180 & 277.6 & 0.0001 \\
Soil depth $\times$ time & 4 & 180 & 7.6 & 0.0001 \\
Weed competition $\times$ soil depth $\times$ time & 8 & 180 & 3.6 & 0.0006 \\
\hline
\end{tabular}




\section{Time* competition*depth}

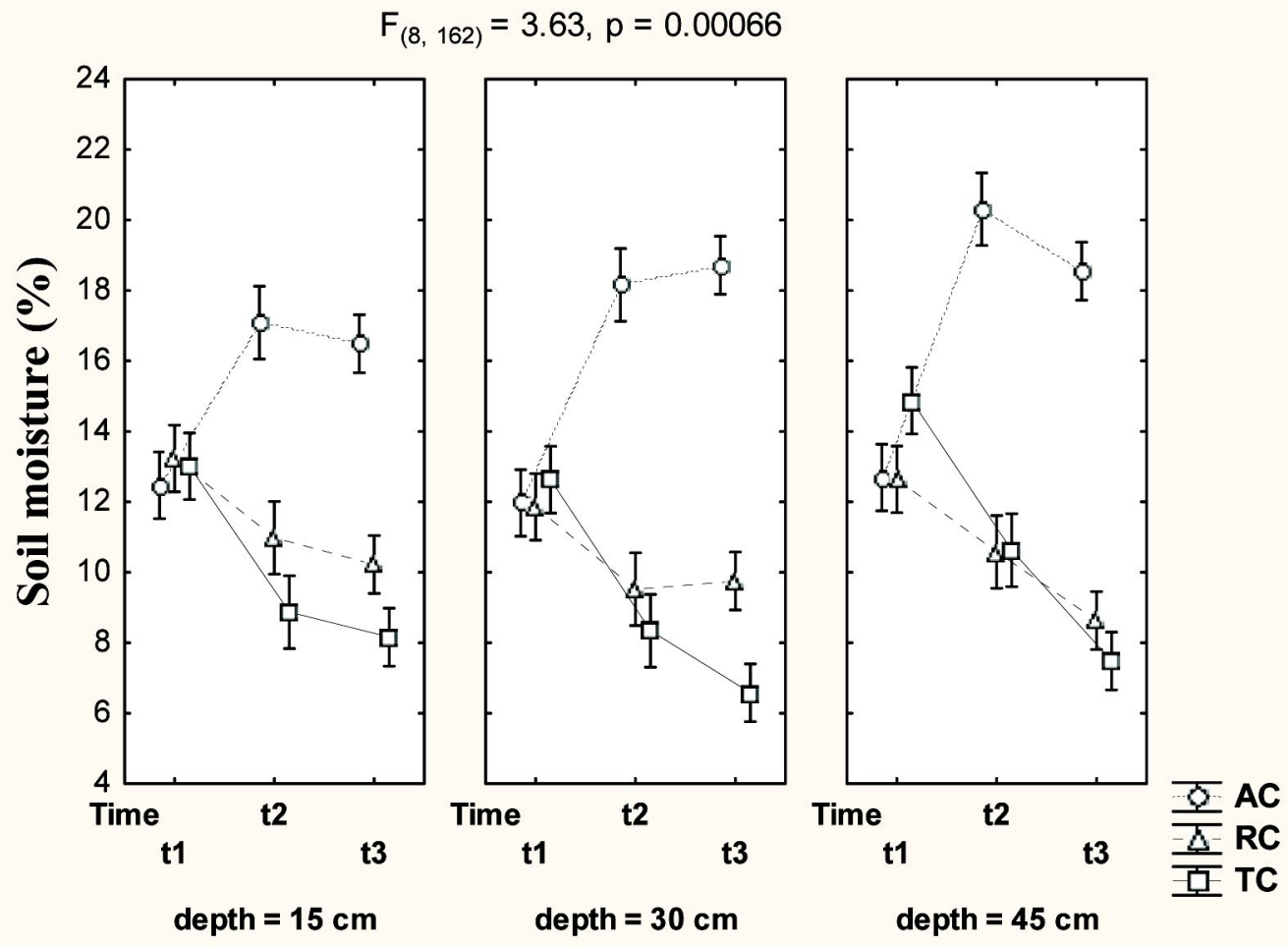

Fig. 1. Variation of soil moisture with herb competition, soil depth, and time before the application of the irrigation treatment. $\mathrm{AC}=$ absence of competition; $\mathrm{RC}=$ reduced competition, $\mathrm{TC}=$ total competition. Time notation is as follows $: \mathrm{t} 1=15 \mathrm{March}, \mathrm{t} 2=5 \mathrm{May}$, and $\mathrm{t} 3$ = 22 May. Every point in the graph is the average of 20 measurements. Bars are standard errors.

Mass allocated to leaves $\left(\mathrm{F}_{2,12}=5.14, \mathrm{p}=0.024\right)$ and roots $\left(\mathrm{F}_{2,12}=4.48, \mathrm{p}=0.035\right)$ differed among competition treatments (Table 2). For leaves, it followed the rank TC < $\mathrm{RC}<\mathrm{AC}$, whereas for roots it followed the inverse rank (TC > RC > AC). Allocation to stems was not affected by competition $\left(\mathrm{F}_{2,12}=0.58, \mathrm{p}=0.57\right.$, Table 2). The shoot:root ratio and total leaf area differed among competition treatments $\left(\mathrm{F}_{2,12}=3.95, \mathrm{p}=0.048\right.$ and $\mathrm{F}_{2,12}=11.81$, $\mathrm{p}=0.0018$, respectively), and they followed the rank $\mathrm{TC}<$ $\mathrm{RC}<\mathrm{AC}$ (Table 2). Mean leaf area was not affected by competition $(\mathrm{p}=0.28)($ Table 2$)$.

\section{Discussion}

We found significant effects of herb competition and irrigation on herb production, soil moisture and seedling performance, evaluated as mortality, growth, morphological, and physiological responses. Under our experimental conditions, herbs strongly competed with $Q$. coccifera seedlings, reducing their establishment success. Furthermore, the potentially positive effects of irrigation on seedling performance were cancelled out by enhanced competition intensity from herbs. Plant interactions are dynamic rela- tionships and positive and negative interactions act simultaneously, the outcome depending on abiotic conditions (Berkowitz et al. 1995, Pugnaire and Luque 2001). In fact, other studies have shown facilitation or neutral effects of herbs for the recruitment of woody species in environments under more severe abiotic conditions (e.g. less water availability and higher radiation inputs) and less herb density (Koukoura and Menke 1995, Rejmanek and Leps 1996, Brown and Archer 1999, Paez and Marco 2000, Maestre et al. 2001).

\section{Herb production and soil moisture}

In our study, clipping reduced above- and below-ground growth of herbs, so herbs did not exhibit an efficient compensation mechanism and were not able to "escape" from this disturbance (Paige and Whitham 1987, Briske and Anderson 1992, Lennartsson et al. 1997, 1998, Taylor et al. 1997). Leriche et al. (2004) also found that total herb yield was higher in control than in clipped treatments.

The intensity of herb competition was related to the pattern of soil desiccation. This desiccation effect has been widely observed in numerous studies about the influence 
a)

\section{Competition* Irrigation}

$\mathrm{F}_{(1,26)}=12.5, \mathrm{p}=0.0015$

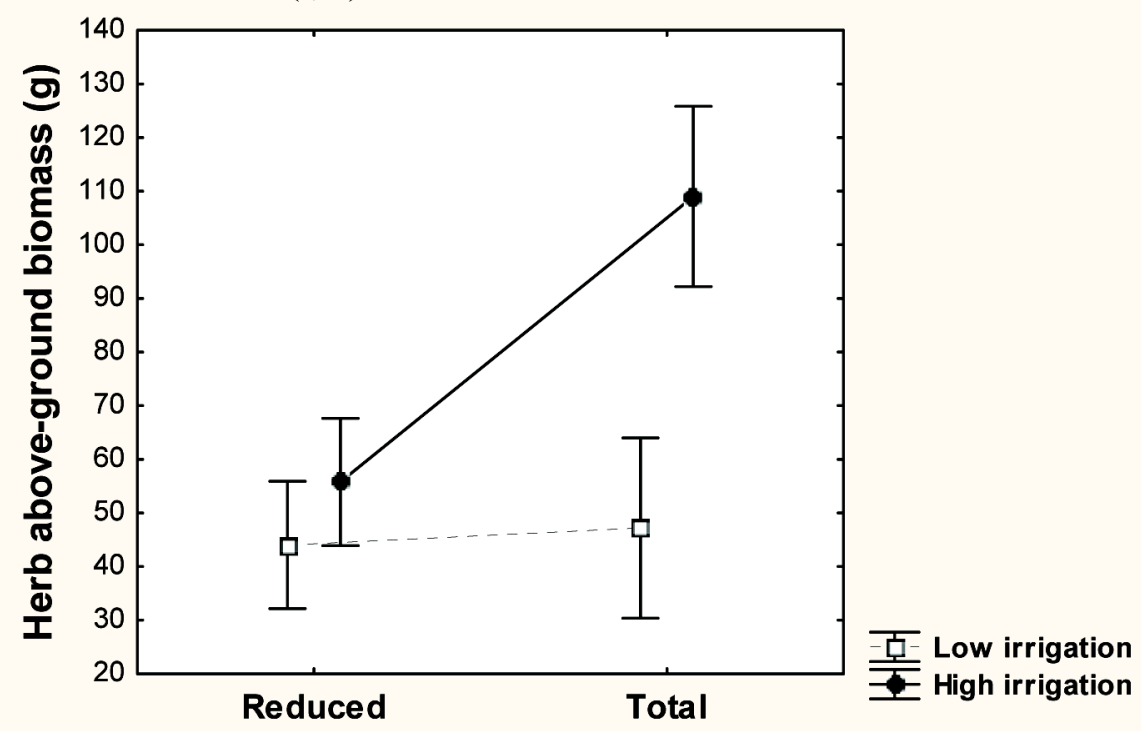

b)

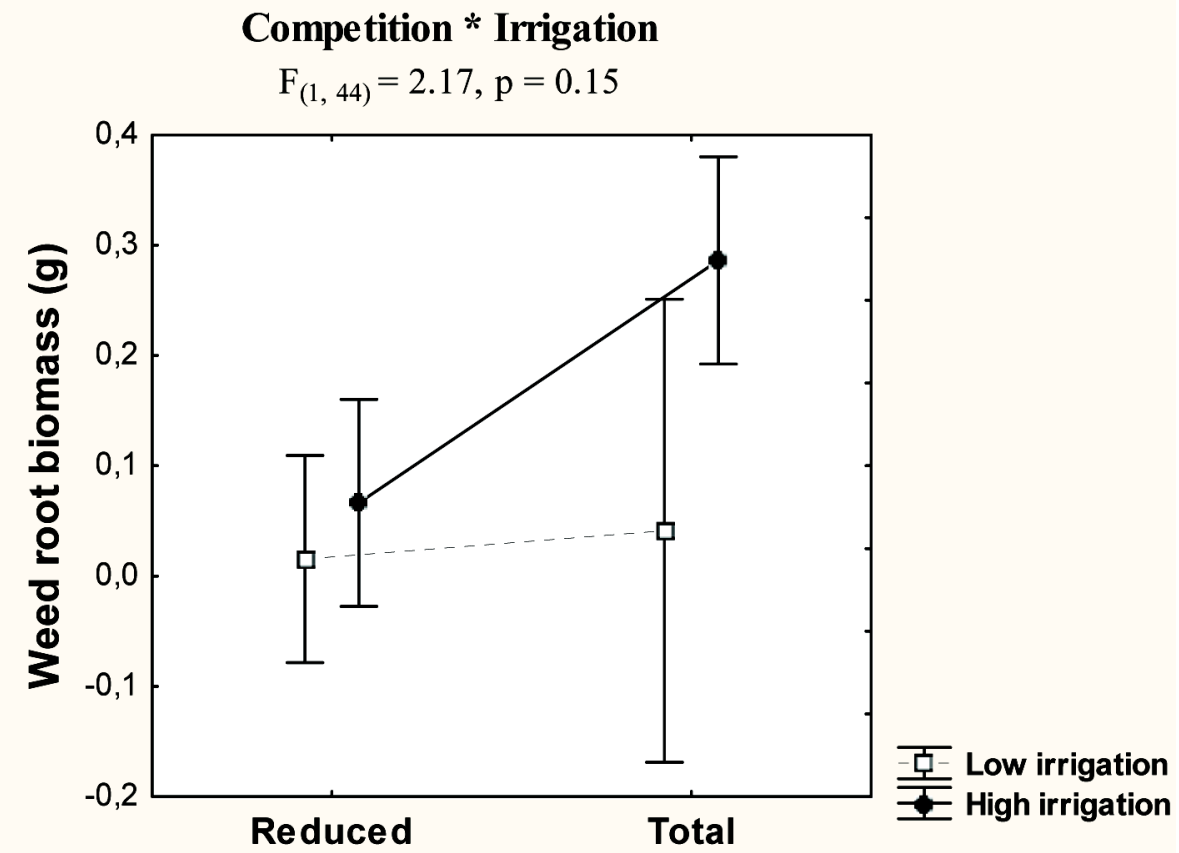

Fig. 2. Interactive effects of herb competition and irrigation on herb production. (a) herb above-ground biomass accumulated throughout the experiment. (b) root biomass of herbs at the end of the experiment. Bars are standard errors. 


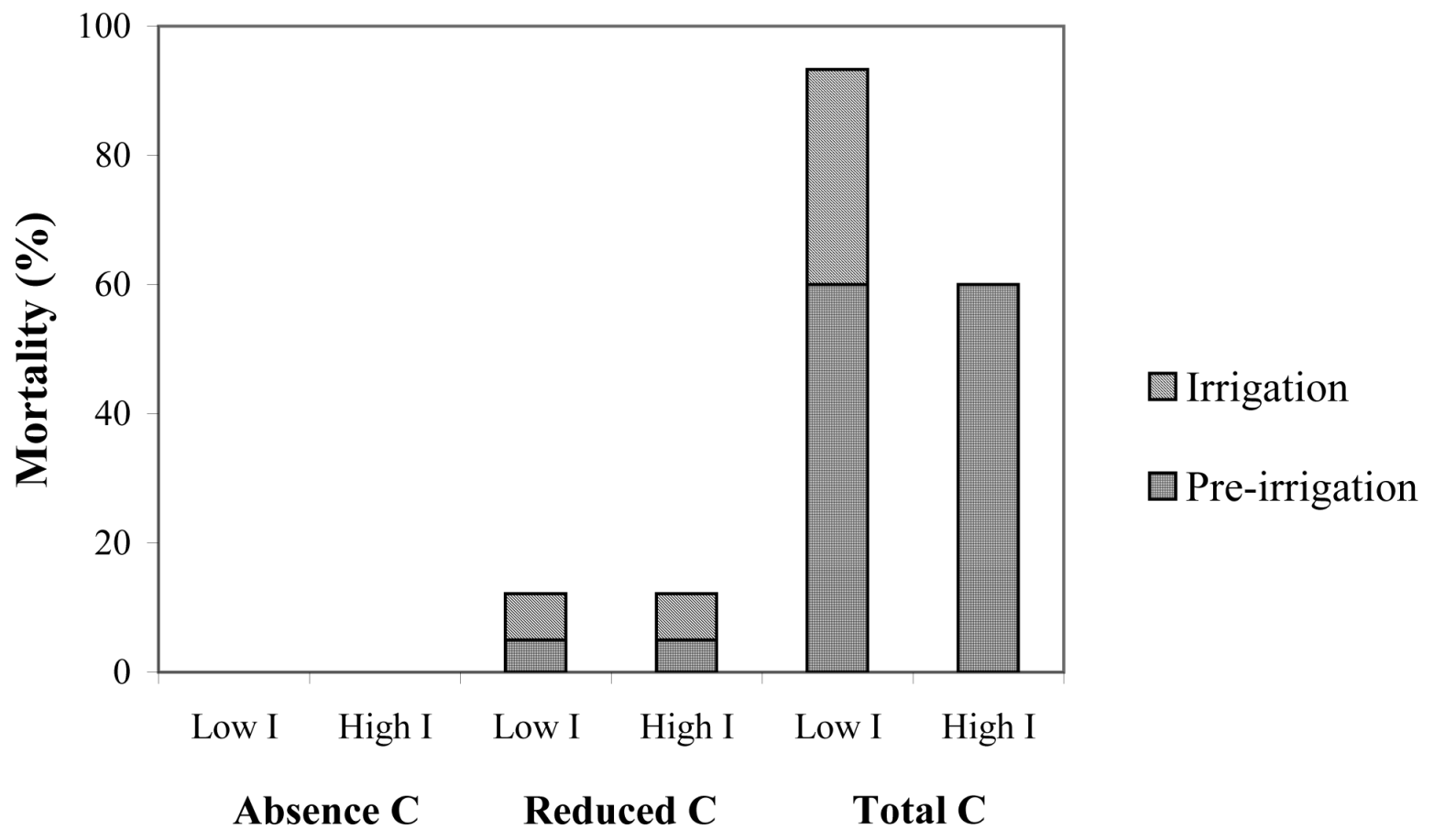

Fig. 3. Percentage mortality of the planted Q. coccifera seedlings under the various experimental conditions (absence of competition, reduced competition, total competition, and low or high irrigation) at two stages of the experiment (before and after differential irrigation treatments). Notes: the percentages after the irrigation treatment exclude the sacrificed seedlings at the end of the preirrigation period; mortality was 0 in Absence of competition; during the pre-irrigation period, mortality bars are by definition identical in the "low" and "high" irrigation treatments.

of herb competition on the establishment of woody seedlings (Knoop and Walker 1985, Zutter et al. 1986, Harrington 1991, Rey Benayas et al. 2005). The amount of herb above-ground biomass produced in the $\mathrm{RC}$ treatment was negatively correlated with soil moisture, suggesting that a greater standing crop transpired more water and hence caused a reduction in soil water availability for seedlings. As expected, herb production was higher under high irrigation conditions, hinting that this treatment increased competition intensity against $Q$. coccifera seedlings, and that the ability of herbs to take advantage of enhanced conditions was much higher than that of the $Q$. coccifera seedlings. The soil moisture profile indicated that increased transpiration from herbs outweighed the reduction in soil moisture evaporation as a result of shading by herbs (Rey Benayas et al. 2002, 2003, 2005).

Moisture reduction increased throughout the growth period, when water shortage is greatest and temperatures higher. Differences in soil moisture between the RC and TC treatments were very small both one month after the beginning of the experiment, when much of this moisture might have been consumed by the germination of herb seeds and their initial growth (López-Pintor et al. 2000, Rebollo et al. 2001), and at the end of the experiment, when soil water was so low that it caused high herb and $Q$. coccifera seedling mortality.

\section{Seedling response to herb competition and water availability}

The TC treatment exhibited higher seedling mortality than the AC and RC treatments. In other words, reduction of herb competition translated into higher survival of planted Q. coccifera seedlings, primarily as a result of mortality reduction before the beginning of the severe drought season. The high mortality in this experiment relative to field conditions may be partially explained by water availability which is commonly lower in containers than in the field, and by restrictions in root growth causing much higher root to soil ratio. Irrigation treatments after the initial growth phase did not have any effects on seedling mortality, further indicating that the potential benefits of additional water for seedlings are cancelled out by its advantageous use by competing herbs. Rey Benayas et al. (2002) also found a positive effect of herb clipping on seedling survival of planted Retama sphaerocarpa (a xerophytic and helliophilous shrub) seedlings. However, in a similar ex- 
a)

Competition effects

$F_{(2,12)}=14.27, p=0.00067$

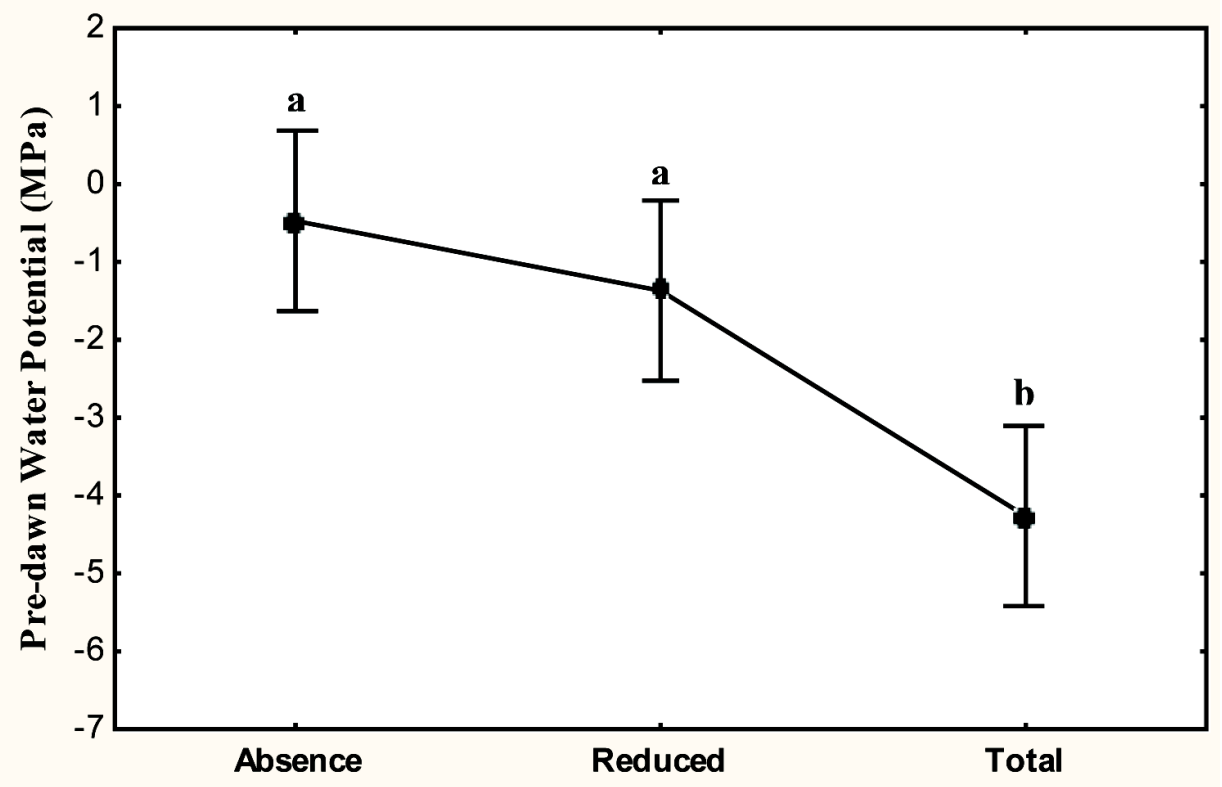

b)

Competition effects

$F_{(2,12)}=27.91, p=0.00003$

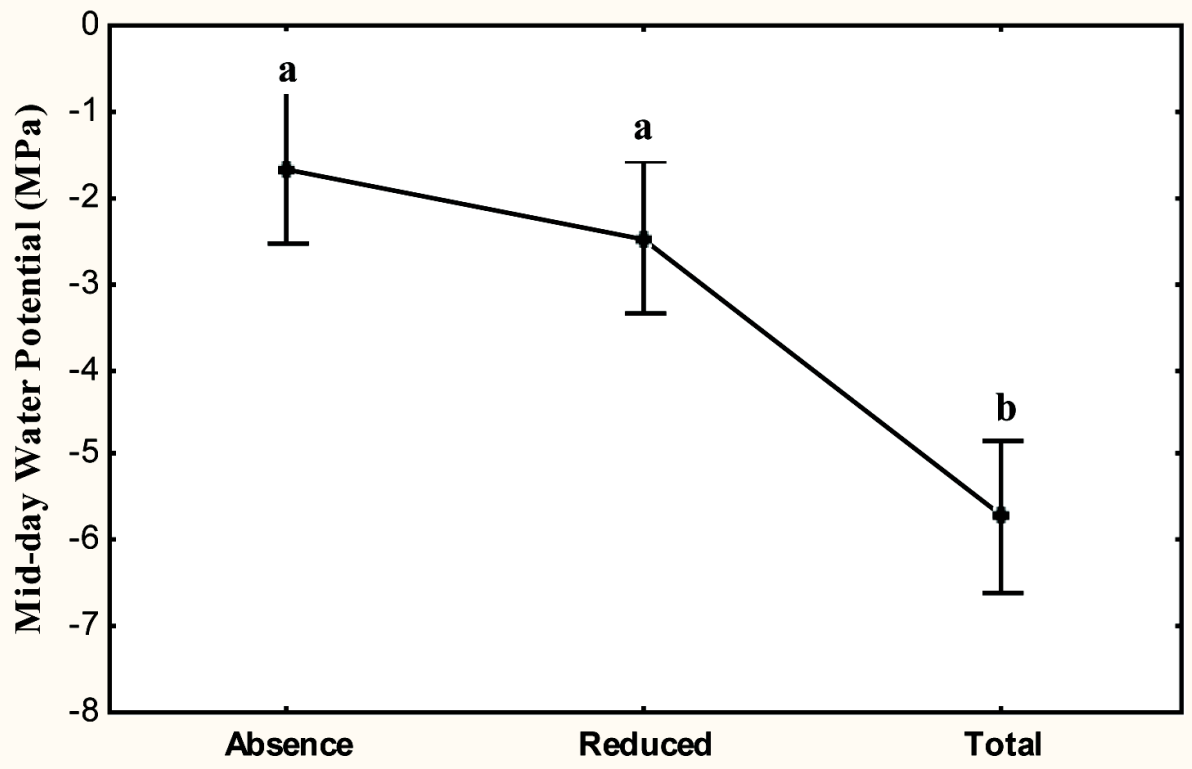

Fig. 4. Variation of pre-dawn (a) and mid-day (b) water potential at each weed competition treatment. The comparison between treatments is based on Tukey's post-hoc tests (nominal p-value $<0.05$ ). Bars are standard errors. 
Table 2. Values (mean \pm SD) of total seedling biomass in the three competition treatments before the application of the irrigation treatment; leaf, stem, and root weight ratios; shoot:root mass ratio; total leaf area; and mean leaf area. Differences between treatments at $\mathrm{p}<0.05$ according to a Tukey's test are indicated with superscripts (note: variable values with no superscripts are not significantly different among treatments).

\begin{tabular}{llll}
\hline & $\begin{array}{l}\text { Absence of } \\
\text { competition }\end{array}$ & $\begin{array}{l}\text { Reduced } \\
\text { competition }\end{array}$ & $\begin{array}{l}\text { Total } \\
\text { competition }\end{array}$ \\
\hline Total seedling biomass (g) & $10.22 \pm 3.29^{\mathrm{a}}$ & $11.69 \pm 2.95^{\mathrm{a}}$ & $6.77 \pm 1.19^{\mathrm{b}}$ \\
Leaf weight ratio (\%) & $23.45 \pm 7.37^{\mathrm{a}}$ & $15.45 \pm 4.28^{\mathrm{ab}}$ & $11.56 \pm 5.88^{\mathrm{b}}$ \\
Stem weight ratio (\%) & $14.64 \pm 6.88^{\mathrm{b}}$ & $14.8 \pm 9.12$ & $10.45 \pm 5.19^{\mathrm{b}}$ \\
Root weight ratio (\%) & $61.91 \pm 6.64^{\mathrm{a}}$ & $69.75 \pm 12.48^{\mathrm{ab}}$ & $77.99 \pm 4.06^{\mathrm{b}}$ \\
Shoot:root ratio & $0.63 \pm 0.18^{\mathrm{a}}$ & $0.47 \pm 0.28^{\mathrm{ab}}$ & $0.28 \pm 0.07^{\mathrm{b}}$ \\
Total leaf area $\left(\mathrm{cm}^{2}\right)$ & $108.3 \pm 12.49^{\mathrm{a}}$ & $75.39 \pm 12.49^{\mathrm{a}}$ & $22.38 \pm 13.244^{\mathrm{b}}$ \\
Mean leaf area $\left(\mathrm{cm}^{2}\right)$ & $1.32 \pm 0.41$ & $1.52 \pm 0.41$ & $0.58 \pm 0.44$ \\
\hline
\end{tabular}

periment to this study, Rey Benayas et al. (2003) did not find any positive effects of clipping on the survival of $Q$. faginea seedlings, probably because $Q$. coccifera is a xerophityc shrub and $Q$. faginea is a mesic tree for which environmental conditions surpassed its threshold of tolerance to drought. Brown et al. (1998) imposed different levels of grass clipping intensity and did not find any effects on shrub seedling survival. Anderson et al. (2001) found that competition for water was a key mechanism in oak-understory interactions. Hill et al. (1995) pointed out that the duration of competition was more important than the initial intensity of competition in determining tree establishment. Other studies have highlighted the importance of herb clipping and herbicide treatments for the success of reforestation practices (Flemming and Wood 1996, Peñuelas et al. 1996, Holl 1998, Imo and Timmer 1998). Thus, the success of woody seedling establishment may be mainly related to water accessibility below the rooting zone of herbaceous vegetation (Henkin et al. 1998, Rey Benayas et al. 2005).

Repeated herb clipping reduced above-ground competition and had a slight reduction of below-ground competition, but may have facilitated shrub growth by soil nutrient release (Muller et al. 2000). Part of the root network would have been lost after each clipping through mobilization of root carbohydrates to support above-ground regrowth and a reduced capacity of the smaller canopy to support roots. Our experiment did not address soil nutrient status relative to the treatments. However, it is likely that competition was mostly for water, because the soil was not infertile, and we consider nutrient enrichment through clipping of little importance.

The pattern of soil moisture in the competition treatments may explain, in part, the differences in $\varphi$ found in Q. coccifera seedlings. Both $\varphi_{\mathrm{pd}}$ and $\varphi_{\min }$ of seedlings subjected to the $\mathrm{AC}$ and $\mathrm{RC}$ treatments were higher that those of seedlings in the TC treatment, where water availability was lowest. This means that clipping ameliorated water stress for seedlings. In contrast to $\varphi$, we did not find differences in the fluorescence Performance Index between the
$\mathrm{RC}$ and AC treatments, most likely because the photo-systems of this species are very stable under conditions of water stress (Vilagrosa et al. 2003b). There are consistencies in the competition treatment ranking for total plant leaf area, biomass allocated to leaves and roots, shoot:root ratio, and LMA. The competition intensity imposed by the treatments $(\mathrm{TC}>\mathrm{RC}>\mathrm{AC})$ was linked to a parallel reduction in total plant leaf area, biomass allocated to leaves and shoot:root ratio, and an increase in biomass allocated to roots and LMA. The lower total plant leaf area and proportion of biomass allocated to leaves, and the higher LMA are well-known mechanisms to reduce transpiration and an adaptation to environments with low water availability (Castro et al. 1997). Albeit significant, the magnitude of changes in below-ground biomass allocation was rather low (Poorter and Nagel 2000), reflecting the substantial number of studies finding no changes in biomass allocation patterns with reductions in water availability. For instance, Sack and Grubb (2002) found that watering frequency, i.e. drought intensity, did not significantly alter biomass allocation across three irradiance treatments in seedlings of four Mediterranean species. We also expected the inverse relationship between biomass allocated to leaves and roots, which constitutes further evidence of the trade-off in the development of plant tissues aimed at capturing different limiting resources (Ksontini et al. 1998, Tilman 1998, Lewis and Tanner 2000, Valladares 2001).

\section{Plantation management and conclusions}

We acknowledge that extrapolating the results of a container experiment to field conditions is risky. Consequently, this study may have a low predictive value for the relative importance of different mechanisms in inhibiting establishment under natural conditions. Even our low irrigation treatment was comparatively "wetter" than natural rainfall in regions where $Q$. coccifera dominates the native vegetation. However, the water added to the experiment was necessary to run the study due to extreme desiccating 
conditions. There is also ample evidence that legumes, such as Medicago sativa used in our study, may improve soil nutrient availability enhancing plant growth and eventually improve ecosystem-level productivity. As we hypothesized, release of herb competition by clipping increased seedling survivorship in one order of magnitude, and resulted in a net carbon gain comparable to the absence of competition. This carbon gain was mostly related to mass allocated to roots. Our results suggest that negative effects of herbs in the establishment of this xerophytic and heliophillous shrub are a result of competition for both water and light. Quercus coccifera seedlings were not able to cope with low light and water availability simultaneously, as indicated by a high early mortality rate in the total competition treatment. Previous research with more mesic Quercus species such as Q. ilex and Q. faginea highlighted that herb competition was primarily for water (Rey Benayas et al. 2005).

In agreement with our second hypothesis, reduction in herb competition was more critical than irrigation for the establishment of Q. coccifera seedlings because the possible positive effects of irrigation on shrubs were balanced out by indirect negative effects through herb growth. The high irrigation treatment increased soil moisture, but our results indicate that the water surplus was most favourable for herbs. We conclude that in order to improve the management of $Q$. coccifera plantations in abandoned Mediterranean cropland, planted seedlings would benefit from an environment with reduced herb competition during the rainy period before the dry season (Paez and Marco 2000). In answer to our question, clipping of herbs around the woody seedlings is a feasible technique that would greatly improve their performance, and thus it is a valuable alternative to herbicide application. It does not pay to apply irrigation unless seedlings grow in an environment with released competition from herbs. This research is a necessary contribution to the analysis of a possible trade-off between the pursued environmental benefits and risk of soil and water pollution due to herbicide application in protocols for reforestation of Mediterranean abandoned cropland.

Acknowledgements - This research has been funded by the projects REN2000-745 and CGL2004-00355/BOS (CICYT, Spanish government) and S-0505/AMB/0355 REMEDINAL (Madrid Autonomous Community). We are indebted to Ramón Bienes for providing climatic data. We acknowledge the comments and input on a preliminary version of this manuscript from our colleagues Tíscar Espigares, Virginia Sanz, Pedro Villar and Miguel A. Zavala. Three anonymous reviewers improved the contents and presentation of this manuscript.

\section{References}

Anderson, L. J. et al. 2001. Water and tree-understory interactions: a natural experiment in a savanna with oak wilt. Ecology 82: 33-49.
Aronson, J. et al. 1998. Restoration ecology studies at Cazarils (southern France): biodiversity and ecosystem trajectories in a Mediterranean landscape. - Landscape Urban Plan. 41: 273-283.

Balaguer, L. et al. 2001. Population divergence in the plasticity of the response of Quercus coccifera to the light environment. Funct. Ecol. 15: 124-135.

Bakker, J. P. et al. 1998. Plant species diversity and restoration ecology: Introduction. - Appl. Veg. Sci.1: 3-8.

Berkowitz, A. R. et al. 1995. Competition vs facilitation of tree seedling growth and survival in early successional communities. - Ecology 76: 1156-1168.

Briske, D. D. and Anderson, V. J. 1992. Competitive ability of the bunchgrass Schizachyrium scoparium as affected by grazing history and defoliation. - Vegetatio 103: 41-49.

Brown, J. R. and Archer, S. 1999. Shrub invasion of grassland: recruitment is continuous and not regulated by herbaceous biomass or density. - Ecology 80: 2385-2396.

Brown, J. R. et al. 1998. Competition by herbs as a limiting factor in shrub invasion in grassland: A test with different growth forms. - J. Veg. Sci. 9: 829-836.

Canham C. D. et al. 1996. Biomass allocation and multiple resource limitation in tree seedlings. - Can. J. For. Res. 26: $1521-1530$

Castro-Díez, P. et al. 1997. Leaf morphology and leaf chemical composition in three Quercus (Fagaceae) species along a precipitation gradient in NE Spain. - Trees 11: 127-134.

Davis, M. A. et al. 1999. Survival, growth, and photosynthesis of tree seedlings competing with herbaceous vegetation along a water-light-nitrogen gradient. - Plant Ecol. 145: 341-350.

Harrington, G. N. 1991. Effects of soil moisture on shrub seedling survival in a semi-arid grassland. - Ecology 72: 11381149.

Henkin, Z.et al. 1998. End-of-season soil water depletion in relation to growth of herbaceous vegetation in a sub-humid Mediterranean dwarf-shrub community on two contrasting soils. - Plant Soil 202: 317-326.

Hill, J. D. et al. 1995. Patterns and causes of resistance to tree invasion in rights-of-way. - Ecol. Appl. 5: 459-470.

Holl, K. D. 1998. Effects of above- and below-ground competition of shrubs and grass on Calophyllum brasiliense (Camb.) seedling growth in abandoned tropical pasture. - For. Ecol. Manage. 10: 187-195.

Hooper, E. et al. 2002. Responses of 20 native tree species to reforestation strategies for abandoned farmland in Panama. Ecol. Appl. 12: 1626-1641.

Hunt, R. and Cornelissen, J. H. C. 1997. Physiology, allocation and growth rate: a reexamination of the Tilman model. Am. Nat. 150: 122-130.

Imo, M. and Timmer, V. R. 1998. Vector competition analysis: A new approach for evaluating vegetation control methods in young black spruce plantations. - Can. J. Soil Sci. 78: 3-15.

Joffre, R. et al. 2001. Respuesta de las plantas mediterráneas a la limitación de agua: desde la hoja hasta el dosel. - In: Zamora, R. and Pugnaire, F. I. (eds), Ecosistemas mediterráneos. Análisis funcional, CSIC-AEET, pp. 37-65.

Knoop, W. T. and Walker, B. H. 1985. Interactions of woody and herbaceous vegetation in a southern African savanna. - J. Ecol. 73: 235-253.

Kollmann, J. and Reiner, S. A. 1996. Light demands of shrub seedlings and their establishment within scrublands. - Flora 191: 191-200. 
Koukoura, Z. and Menke, J. 1995. Competition for soil water perennial bunch-grass (Elymis glaucus B.B.) and blue oak seedlings (Quercus douglasii $\mathrm{H}$. and A.). - Agroforest. Syst. 32: 225-235.

Ksontini, M. et al. 1998. Comparison of the waters stress effects on stomatal conductance, photosynthesis and growth of Mediterranean oak seedlings (Quercus suber L., Q. faginea, $Q$. coccifera) in Tunisia. - Ann. Sci. For. 55: 477-495.

Lemieux, C. and Delisle, C. 1998. Using cover crops to establish white and black spruce on abandoned agricultural lands. Phytoprotection 79: 21-33.

Lennartsson, T. et al. 1998. Induction of overcompensation in the field gentian, Gentianella campestris. - Ecology 79: 1061-1072.

Leriche, H. et al. 2004. Grass response to clipping in an African savanna: testing the grazing optimisation hypothesis. - Ecol. Appl. 13: 1346-1354.

Lewis, S. L. and Tanner, E. V. J. 2000. Effects of above- and belowground competition on growth and survival of rain forest tree seedlings. - Ecology 81: 2525-2538.

López-Pintor, A. et al. 2000. Effect of simulated parent-created microenvironmental conditions on germination of Retama sphaerocarpa (L.) Bois. seeds. - J. Med. Ecol. 1: 219-226.

Maestre, F. T. et al. 2001. Potential for using facilitation by grasses to establish shrubs on a semiarid degraded steppe. - Ecol. Appl. 11: 1641-1655.

Morris, L. A. et al. 1993. Competitive interference between selected herbaceous and woody plants and Pinus taeda L. during two growing seasons following planting. - For. Sci. 39: $166-187$.

Muller, I. et al. 2000. The effect of nutrient availability on biomass allocation in 27 species of herbaceous plants. - Perspect. Plant Ecol. Evol. Syst. 3: 115-127.

Paez, S. A. and Marco, D. E. 2000. Seedling habitat structure in dry Chaco forest (Argentina). - J. Arid Environ. 46: 57-68.

Paige, K. N. and Whitham, T. G. 1987. Overcompensation in response to mammalian herbivory: the advantage of being eaten. - Am. Nat. 129: 407-416.

Paraskevopoulos, S. P. et al. 1994. Plant growth strategies in evergreen-sclerophyllous shrublands (Maquis) in central Greece. - Vegetatio 115: 109-114.

Padgett, P. et al. 2000. The effects of irrigation on re-vegetation of semi-arid coastal sage scrub in southern California. - Environ. Manage. 26: 427-435.

Peñuelas, J. L. et al. 1996. Experiencias sobre el control de la competencia herbácea en repoblaciones de terrenos agrícolas abandonados. - Montes 45: 30-36.

Poorter, H. and Nagel, O. 2000. The role of biomass allocation in the response of 546 plants to different levels of light, CO2, nutrients and water: a quantitative review. - Austr. J. Plant Physiol. 27: 595-607.

Pugnaire, F. I. and Luque, M. T. 2001. Changes in plant interactions along a gradient of environmental stress. - Oikos 93: 42-49.

Rambal, S. and Leterme, J. 1987. Changes in aboveground structure and resistances to water uptake in Quercus coccifera along a rainfall gradient. - In: Tenhunen, J. D. et al. (eds), Plant response to stress. Functional analysis in Mediterranean ecosystems. NATO ASI ser., Springer, pp. 191-200.

Rambal, S. et al. 1996. Optimization of carbon gain in canopies of Mediterranean evergreen oaks. - Ann. Sci. For. 53: 547560.
Rebollo, S. et al. 2001. Recruitment in a Mediterranean annual plant community: seed bank, emergence, litter, and intraand interspecific interactions. - Oikos 95: 485-495.

Rejmanek, M. and Leps, J. 1996. Negative associations can reveal interspecific competition and reversal of competitive hierarchies during succession. - Oikos 76: 161-168.

Rey Benayas, J. M. 1998. Growth and mortality in Quercus ilex L. seedlings after irrigation and artificial shading in Mediterranean set-aside agricultural lands. - Ann. Sci. For. 55: 801-807.

Rey Benayas, J. M. et al. 2002. Early establishment of planted Retama sphaerocarpa seedlings under different levels of light, water and weed competition. - Plant Ecol. 159: 201-209.

Rey Benayas, J. M. et al. 2003. Effects of herb competition on planted Quercus faginea seedlings in Mediterranean cropland. - Appl. Veg. Sci. 6: 213-222.

Rey Benayas, J. M. et al. 2005. Effects of artificial shading and weed mowing in reforestation of Mediterranean abandoned cropland with contrasting Quercus species. - For. Ecol. Manage. 212: 302-314.

Rey Benayas, J. M. et al. 2007. Abandonment of agricultural land: an overview of drivers and consequences. - Perspect. Agr. Vet. Sci. Nutr. Nat. Res., no. 57.

Rey Benayas, J. M. et al. 2008. Creating woodland islets: a new approach to reconcile ecological restoration, conservation, and agricultural land use. - Front. Ecol. Environ., in press.

Rousset, O. and Lepart, J. 2000. Positive and negative interactions at different life stages of a colonizing species (Quercus humilis). - J. Ecol. 88: 401-412.

Sack, L. and Grubb, P. J. 2002. The combined impacts of deep shade and drought on the growth and biomass allocation of shade-tolerant woody seedlings. - Oecologia 131: 175-185.

Sala, A. et al. 1994. Canopy structure within a Quercus ilex forested watershed: variations due to location, phenological development, and water availability. - Trees 8: 254-261.

StatSoft. 2001. STATISTICA (Data Analysis Software System), ver. 6. - StatSoft Inc.

Sternberg, M. et al. 2001. Effects of clearing and herbicide treatments on coniferous seedling establishment and growth in newly planted Mediterranean forests. - For. Ecol. Manage. 148: 179-184.

Strasser, R. J. et al. 1996. How to work without stress but with fluorescence. - Bull. Soc. R. Sci. Liége 65: 330-349.

Taylor, K. L. et al. 1997. The effects of herbivory on neighbour interactions along a coastal marsh gradient. - Am. J. Bot. 84:709-715.

Tilman, D. 1988. Dynamics and structure of plant communities. - Princeton Univ. Press.

USDA. 1995. Soil taxonomy. Agriculture handbook 436.

Valladares, F. 2001. Características mediterráneas de la conversión fotosintética de la luz en biomasa: de órgano a organismo. - In: Pugnaire F. and Zamora R. (eds), Ecosistemas mediterráneos. Análisis funcional, pp. 67-93. AEET/CSIC, Madrid.

Valladares, F. and Pugnaire, F. 1999. Tradeoffs between irradiance capture and avoidance in semi-arid environments assessed with a crown architecture model. - Ann. Bot. 83: 459-469.

Vieira, I. C. G. et al. 1994. The role of the shrub Cordia multispicata Cham. as a 'succession facilitator' in an abandoned pasture, Paragominas, Amazonia. - Vegetatio 115: 91-99.

Vilagrosa, A. et al. 2003a. Suitability of drought-preconditioning techniques in Mediterranean climate. - Rest. Ecol. 11: 208216. 
Vilagrosa, A. et al. 2003b. Cavitation, stomatal conductance, and leaf dieback in seedlings of two co-occurring Mediterranean shrubs during an intense drought. - J. Exp. Bot. 54: 20152024.

Villar-Salvador, P. et al. 1997. Stem xylem features in three Quercus (Fagaceae) species along a climatic gradient in northeast Spain. - Trees 12: 90-96.
Whisenant, S. G. et al. 1995. Initiating autogenic restoration on shallow semiarid sites. - Rest. Ecol. 3: 61-67.

Zutter, B. R. et al. 1986. Effects of herbaceous weed control on a young loblolly pine plantation. - For. Sci. 32: 882-899. 